\title{
Secession and the Reformed ('Dopper') Churches in South Africa'
}

Bouke Spoelstra, Potchefstroom

\section{OPSOMMING}

Afskeiding en die Gereformeerde ('Dopper') Kerke in Suid-Afrika Die Afskeiding van 1834 in Nederland het die kenmerke van die ware kerk (art. $29 \mathrm{NGB}$ ) op die wetlik omlynde instituut van die staatskerk toegepas. Volgens hierdie model moes die motief vir die afskeiding van 1859/60 ook die stigting van 'n opponerende instituut met eie kenmerke teenoor die staatskerke in Transvaal, ovs en Kaapkolonie gewees het of die Christelijke Gereformeerde Kerk waaruit ds Postma gekom het, moes aangegryp gewees het.

Hierdie studie toon aan dat gelowiges in die wyse waarop hulle plaaslik bediening en kerkregering ervaar het intuitief tot die slotsom gekom het dat dit nie aan die kenmerke van ware kerk-wees beantwoord nie. Mense wat aan die gesag van Gods Woord gehoorsaam wou wees, is deur kerkgesag vanaf 1834 onteer en in isolasie gedrywe.

Slegs 'n klein radikale Enslin-groep het in 1853 verwydering van die gesange uit alle eredienste geeis. Die beswaarde groep uit die 'Doppers' het die wat Gesange gesing het, laat begaan, maar hulle wou self nie in hulle godsdiens gedwing word om 'nuwighede' te aanvaar voordat hulle dit met hulle gewete kon rym nie. Om hierdie rede is hulle offisieel deur predikante en kerkvergaderings as "deurboorders van die liggaam van Christus" beledig en vervolg. Hulle vertoe om begrip is geïgnoreer, en hulle kon vir twee dekades nie nagmaal vier nie.

In Transvaal is tydens die konsolidasie van die Republiek in September 1858 offisieel tot 'n eie gemeente vir beswaardes binne die staatskerk toegestem. Die ooreenkoms is in Januarie 1859 opgehef toe die Algemene Kerkvergadering die sing van gesange vir almal verplig het.

Die behoefte aan 'n eie plaaslike bediening wat volgens hulle gewete met Gods Woord en die riglyne van die Sinode van Dordrecht $1618 / 19$ sou ooreenkom, lei tot die stigting van vyf selfstandige, onafhanklike, hoewel innerlik verwante, Gereformeerde kerke (gemeentes) in 1859/60. Hulle stel in 1862 'n federale verband deur middel van die Kerkorde van 1619 daar waarin hulle as selfstandige kerke saamwerk sonder om in 'n groter geheel op te los.

The marks of the true church, as described in art. 29 of the Belgic Confession are applied by Calvin ${ }^{2}$ to the visible local congregation. During the Reformation local ministries were reformed in order to correspond to the marks of the true church of Jesus Christ. During the 18th and 19th centuries the concept of the church changed as a result of rationalism.

60 - In die Skriflig 1989, 23 (4) 
The 'church' is since then understood as a social structure, a static legal persona with a specific constitution and name, a Collegia licita recognised by the secular authorities. As was done during the secession of 1834 in the Netherlands the marks of the true church were ascribed during the 19th and 20th centuries to such ecclesiastical structures as the reason why a 'new church' was established.

The Reformed Churches in South Africa (GKSA) happened to originate in $1859-1860$ in terms of the 16th century's ministerial rather than the later institutional concept of the church. History will testify to the fact that the 'Doppers' and their co-objectionists were, without the leadership of any pastor, concerned with reform of local ministries and public worship. The institution of a particular denomination as such did not concern them. They did not opt for secession because they wanted an alternative 'church'. They tried by all means to remain loyal within the unity of faith, worship and discipline as was determined by the Synod of Dordt $1618 / 19$ in the Netherlands. Their norm was art. 7 of the Belgic Confession. ${ }^{3}$ Because they adhered to this point of view, secession was deliberately forced on the discontented group in 1859.

\section{BACKGROUND}

The commercial, political and ecclesiastical reign of the Dutch East India Company (VOC) in Southern Africa scrupulously protected religion, though exclusively in the Dutch Reformed tradition. Even the practice of Iutheranism was not allowed before 1780 and this matter had not yet been settled when De Mist arrived in 1802. In 1795, during the Napoleonic wars, the rule of the VOC was abruptly terminated by the arrival of British forces.

In performing its religious obligations, the voc was assisted by the distant Classis of Amsterdam in the Netherlands. The number of congregations in the Cape Colony was restricted and these congregations were not allowed to meet and operate in their own classis or synod. Nevertheless, in matters of worship and discipline, the local churches enjoyed freedom and responsibility in the best decentralised Genevan and Dutch traditions. ${ }^{4}$ The more or less independent congregations observed and practised the Reformed faith and discipline to the standards of the Synod of Dordrecht 1618/19.

By the year 1800 a group of closely related families bearing surnames such as inter alia Van der Walt, Venter and Kruger had already settled in the secluded North Eastern regions of the Cape Colony. They were isolated from Cape Town and church 'civilisation' by mountain ranges, vast distances and semi-desert country. Despite their isolation and lack of formal education, these people were well-behaved, law-abiding and God-fearing citizens, practising a Puritan life-style. In most respects they controlled and governed themselves, adhering to their reformed religion and cultural heritage. They neither modified their dress nor remodelled their fashions. They were very un-English but not all antiEnglish. They could attend church services in the remote towns only a few times a year for confirmations, marriages, baptisms or to take Holy Communion.' 
By 1850 these farmers of the North Eastern Cape Colony had been nicknamed 'Doppers' especially by British administrators and liberal citizens of Cape Town who looked upon themselves as enlightened and highly civilised. The Doppers were thus labelled as unenlightened, uneducated, primitive and even as "dirty Dutch". ${ }^{\circ}$ On the other hand professor John Murray of the Dutch Reformed Church, who served as minister in Burgersdorp and vicinity from 1847 to 1859 said that they were "if not the brain, at all events the backbone of the nation that is being formed in South Africa".' Somebody with the penname $Z$ werfgraag (probably John Murray himself) praised the Doppers highly in a Cape Town newspaper during $1857 . .^{8}$ They were also the first and only pioneers who on their own, invented a unique scheme in 1800 to placate and civilize the primitive San or 'Bushmen' hunters.'

These isolated people on the north-eastern border of the Cape Colony lived a free life but were perpetually in danger in various ways. There was always the risk of a loss of cultural identity and social and racial assimilation with the heathens of a primitive African culture due to the proximity of neighbouring San and Khoi-Khoi-tribes, but religion and traditions formed their stronghold. Furthermore, parents preserved their life-style by means of home education of their children. The parents taught their children to read and write, using the Holy Bible and the Heidelberg Catechism. The pater familias daily conducted Scripture reading and devotions for the whole family, including domestic slaves and other coloured servants. On Sundays a complete sermon from a 17th century Dutch 'author' was read. Not only had they developed a strong sense of individuality, they also gave expression to their Reformed religion in their daily lives. Thus the Dutch State Version of the Bible (1622) was the sole and single source of authority in all religious, moral, social and political matters of the day. ${ }^{10}$

It is therefore obvious that their values concerning tradition, individuality, freedom and responsibility to God would bring them into conflict with the newly formed centralised ecclesiastical authorities. When the Presbytery of Graaff Reinet endeavoured to force changes upon them from 1834 to 1853 there was indeed conflict. It is interesting that while approximately only one fifth of the Dopper community seceded from the Dutch Reformed Church in the Cape Colony (DRC), the nickname 'Dopper' was transferred to them. Later on the name was also applied to other objectionists in the Transvaal, who were not even part of the original Dopper community. ${ }^{12}$

\section{THE 19TH CENTURY AS AN ERA OF CHANGE}

In 1804 Mr J.A. De Mist, Commissioner-General of the interim government of the Dutch Batavian Republic in the Cape Colony (1802 - 1806) promulgated a constitution for the church according to the new ideas of the Enlightenment and the French Revolution. By virtue of this Church Order the church was now regarded as a denomination, a centralised body, a legal persona, a collegia licita. According to the philosophy of the 18th century (eg J. J. Rousseau's Le Contrat Social) the autonomous individual enjoys the freedom of religious association and 
constitutes by means of delegation and agreement with others a church to his liking. The Church Order provided state support for the worship of a Highest Being in the 'Dutch Church' mainly to promote virtue and good morals among its subjects. Provision was made for a synod under supervision of the government. The implementation of this provision was, however, postponed. ${ }^{13}$

Two years later the British occupied the Cape Colony for the second time. It became increasingly hard to get Dutch ministers to come to South Africa. In 1820 Governor Somerset decided to introduce ministers from the Scottish Presbyterian Church into the Dutch (Afrikaner) communities. This coincided with his policy of anglicization whereby use of the English language became obligatory in all official communications. ${ }^{14}$

In 1824 these presbyterian ministers induced the Governor to permit the first Synod of the Dutch Reformed Church according to the provisions already made in the Church Ordinance of De Mist in 1804. "Van nou af tree 'n heeltemal nuwe faktor, naamlik die gesentraliseerde kerkbestuur, na vore en dit kom teenoor die eeue-lange tradisie van plaaslike vryheid in die gemeentes te staan. Die Skotte bet in hierdie sentralisasie en eenvormige praktyk geglo ..."1s

The First Synod adopted De Mist's Church Order as the basic constitution of the DRC (NGKSA) while the General Regulations from the same revolutionary background, introduced by King William I in 1816 for the Reformed (Hervormde) Church in the Netherlands, were adapted to constitute a centralised synod with regional presbyteries and local consistories. Up to now this constitution was rejected because of its collegialistic characteristics. ${ }^{16}$ It was typical of presbyterian church polity therein that the authority over the local Church was invested in the presbytery. ${ }^{17}$

Theological liberalism and religious modernism were introduced to the Afrikaans speaking community in Cape Town since the beginning of the 19th Century. Afrikaans speaking and Dutch ministers were trained in liberal theology at universities in the Netherlands. On account of his reason and intellect the autonomy of man was emphasised and identified with enlightenment and being civilised. By the middle of the 19th century some Afrikaans speaking ministers of the DRC rejected teachings of the Heidelberg Catechism in public. ${ }^{18}$ The Scottish ministers played a leading role in opposing the rationalistic and liberal influence by launching a revival movement. There was a direct confrontation between these two groups on the DRC Synod of 1862 . The Supreme Court upheld an appeal by the liberal group and enforced the boundaries of the Cape Colony on the institution of the DRC (NGK).

An immense shift in religious conceptions became obvious in the Cape Colony. This caused unrest and deep concern among the Doppers in the remote rural areas. They were determined to preserve their inherited reformed religion and to protect themselves against the onslaught of liberalism and modernism..$^{19}$ For them there was no reason to change their customs or traditions in any respect, even if they were out of step with the so-called "new light". ${ }^{20}$

In die Skriflig $1989,23(4)-63$ 


\section{TENSION AND RIFT}

By 1830 the British colonial government had established new towns and parishes manned by Scottish clergymen among the Doppers or Trekboere who must not be confused with the Voortrekkers. The Voortrekkers lived in the eastern and south-eastern border districts until they left the Cape Colony from 1834 onwards. They were cattle-farmers who were dissatisfied with the British colonial border policy. The Doppers in the northern and north-eastern border districts on the other hand were sheep-farmers who formally remained loyal to the British rule on account of their interpretation of the Fifth Commandment. A few Dopper families, however, including that of Paul Kruger joined the Trek, more or less coincidently. The Kruger family was destined to play an important role in political and ecclesiastical matters in the Transvaal.

A new Evangelical Hymn Book had been introduced in the Netherlands during the French Revolution. Without any formal appraisal the example was followed by one congregation after the other in the Cape Colony.

The first sign of tension in the DRC occurred in the congregation of Cradock which was attended by people from the later established towns of Colesberg, Burgersdorp and Middelburg. The precentor at Cradock refused to sing the words of a hymn, though he agreed to sing the melody. The Presbytery of Graaff Reinet to which the congregations with substantial Dopper membership belonged, advised the Church Council of Cradock to try to dissuade such persons from their bigotry. ${ }^{21}$ At the same time people who did not belong to the Dopper community, but objected most strongly to the introduction of the hymns, also left the Cape Colony in the Great Trek. ${ }^{22}$

In the newly established neighbouring congregation of Colesberg the Church Council existed of eight members. Half of them just closed their books whenever a hymn was announced. The Scottish minister, Thomas Reid and his supporters, attempted, without success, to enforce the 1833 decision of the Presbytery. Reid refused to baptise the children of those who objected to the hymns because he did not consider them to be true believers. $^{23}$

In 1841 office bearers of Colesberg in favour of singing hymns wrote to the same Presbytery intending to terminate the persistent demonstration of objections. ${ }^{24}$ In 1841 the Presbytery issued an official pastoral circular, not only to the congregation of Colesberg, but also to objectionists in the congregation of Cradock (including the later established Burgersdorp).25

Without proper investigation the Presbytery rejected the objections which claimed that the hymns contained a new gospel. The content of the Pastoral Circular reveals the nature of the objections indicated reference to the principle of article 7 of the Belgic Confession as well as article 69 of the Church Order of the Synod of Dordt 1619. The Presbytery rejected obviously what was argued in the congregations referring the objectionists to the authority of the ministers who accepted the hymns. The Presbytery accused by means of this Pastoral Circular the object-

64 - In die Skriflig 1989, 23 (4) 
ionists of committing a grave sin. They were summoned before the crucified Christ on Calvary to answer why they were persisting in their stubborness thereby piercing Christ's bleeding side and tearing his body apart. They were entreated by the Circular to humble themselves for the sake of unity.

This action was seen as a "uiterste konsekwensie van die Liberalisme", 26 and can be regarded as a manifestation of collegialism. ${ }^{27}$ It may also be a consequence of presbyterianism where the Presbytery (especially the ministers) rules the congregation on behalf of the unified church. ${ }^{28}$

The attitude of the Presbytery proved disastrous. The objectionists reacted strongly to being blemished as desecrators of the body of Christ. Being branded by an official ecclesiastical body they abstained from Holy Communion year after year. If the label was valid, they reasoned, the liturgical formulary of selfexamination excluded such persons from communion. They demanded that the ecclesiastical courts restore their good name and standing within the churches.

In 1847 a Colesberg deacon, Jan H. Venter, appealed to the Synod in Cape Town to have the defamatory allegations in the Presbytery's pastoral Circular withdrawn. He pointed out that in matters of religion these people did not want the convictions of others forced upon them. The synodical committee supported the appeal. The DRC Synod (NGK) nevertheless upheld the Presbytery's official pronouncements. ${ }^{29}$ In 1849 Venter again pleaded with the Presbytery on behalf of "het grootste gedeelte van de Gemeente van Colesberg" to withdraw the offence embodied in the Pastoral Circular of 1841 in order that the Lord might again bless the congregation in holy communion "tot Zijn eer" ${ }^{30}$ Venter and his supporters pressed for the removal of the insult laid on them in 1841 . and did not demand the removal of the hymns. The ministry in the local congregation was the focus point of their complaints and appeals. No attack was launched on the church structures as such.

Fuel was added to the fire of discontent when the rev Reid, without consulting the Church Council permitted the Anglican bishop Gray to conduct a service in the NGK of Colesberg during his visition tour to the region. ${ }^{31}$ The dissatisfied people asked the Presbytery whether "onze Reformatie onder een gedwongen godsdienst bestaat of niet". ${ }^{32}$ The widespread discontent that resulted united the faithful, those in favour of as well as those against the Evangelical Hymns, to reject the ministry of the rev Reid. A third of the congregation independently obtained the services of the Rev John Murray from the neighbouring congregation of Burgersdorp who ministered to them on the farms of Venter and Celliers. "In 1851 the Presbytery had to agree with the petitioners that chaos prevailed in Colesberg. They passed the problem on to the Synod of $1852 .{ }^{34}$ The impotence of the Presbytery to restore order in the local congregation became a matter of great concern among these unfortunate people." In 1852 the synod advised the transfer of the minister and in the meantime allowed the discontented part of the congregation to have its own separate services conducted by the rev John Murray of Burgersdorp. ${ }^{36}$

In die Skriflig $1989,23(4)-65$ 
In order to terminate the disruptions in Colesberg, the Presbytery arranged in 1853 that the rev Reid would resign from his position under payment of the amount of one thousand two hundred and fifty pounds by ten members of the congregation, inter alia J. H. Venter, J. P. and H. J. van der Walt and a shopkeeper, A. Ortlepp. This arrangement had been properly effected by a notary public in Graaff Reinet with full consent of the Presbytary. ${ }^{37}$ This painful history witnesses to the fact that these tenacious objectors tried to reform the ministry over long years, even though they received little help from the official ecclesiastical bodies.

After the rev Reid has resigned his office in the Presbytery he sued the above mentioned petitioners in the Supreme Court for damages. His claim was formally granted in 1856 and he was allowed one pound for damages. The defendants were also ordered to pay the costs of the suit. ${ }^{38}$ Thus they suffered a severe financial setback in order to restore peace in the ministry of Colesberg. The Presbytery remained a mere bystander to these proceedings. Two of the defendants, J. H. Venter and J. P. van der Walt, sold their substantial properties in the Cape Colony immediately after the verdict and moved north to play a leading role in the secession of the Reformed Churches in $1859 .{ }^{39}$

Although less discontent rifted in Burgersdorp which previously belonged to the congregation of Cradock, the same suffering under the Pastoral Letter of 1841 prevailed with the result that great numbers of members abstained from holy communion. ${ }^{40}$

Reid's trial drew much public attention and the quaintness of the Doppers was openly discussed in the Cape Town papers. To hold such strong religious convictions against educated ministers of religion was incredible in times when modernism linked civilisation to formal education. But even then an authoritative contributor, using the pen-name 'Zwerfgraag' (probably John Murray), testified at length in the liberal Cape Town newspaper, Het Volksblad, to the loyalty of the Doppers to their church, religion, government, Puritan way of life and excellence of character. ${ }^{41}$

The rev P. Huet of the DRC in Pietermaritzburg, observed in 1860: "Ik geloof dat ds Postma gelijk heeft met te zeggen, dat de Afscheiding hier te lande, reeds v06r zijne komst feitelijk bestond . . . Ik geloof dat in hen . . . een sluimerend, zich onbewust gevoel van gemis aan Calvinistische prediking hun door oude Gereformeerde boeken overgeleverd, bestond . . . Ik geloof . . . dat hun nauwgezet vasthouden aan de Bijbel met kanttekeningen, en hun verkleefdheid aan de oude Calvinistische leer een middel is geweest tot bewaring wat aan verscheidene plaatsen anders geheel verloren ware gegaan - de Gereformeerde Kerkleer." 42

\section{THE COLESBERG-STRUGGLE EXTENDED TO BLOEMFONTEIN}

Since 1847 several protesters from the Colesberg-Burgersdorp area in the Cape Colony trekked and resettled in the southern parts of the Orange Free State. Because the British controlled the region before 1854 the rev Andrew Murray was appointed by the Governor of the Cape Colony in 
1849 to be the Dutch Reformed minister of religion in Bloemfontein. The Orange Free State gained its independence as an independent Boer (Afrikaner) Republic from Britain in 1854. Koos Venter, formerly from Colesberg, became vice-president. Soon there was conflict between Venter and the rev Andrew Murray, who was opposed to the independence of the young republic and even petitioned against it in England. ${ }^{43}$

Andrew Murray and his brother John of Burgersdorp were the sons of the Scottish minister of Graaff Reinet and were trained for the ministry in Scotland. Their religious convictions were connected with the so-called Marrow-men in Scotland. ${ }^{44}$ After 1857 Andrew Murray became a wellknown leader of the revival movement in the NGK. He was strongly influenced by John Wesley and has widely been accused of semiPelagianism. ${ }^{45}$

Nevertheless, since 1856 the 'revival'-movement in the NGK gained momentum against the growing influence of liberalism and modernism. The revival approach differed from that of the Doppers who accepted unconditionally the covenantal relationship with a sovereign God. Andrew and his brother John conceded that they were unable to fathom the religious mind of the true Dopper. ${ }^{46}$

The rev P. Huet, another minister in the DRC (NGK) at that time, was convinced that the failure to teach true Reformed doctrines from the pulpit caused the general discontent amongst the Doppers. ${ }^{47}$ The launching of an evangelical campaign for revival within the NGK coincided in 1859 with the secession of the Reformed Churches (GKSA).

It is difficult to tell to what extent the interwoven political and ecclesiastical troubles in Transvaal as well as Dopper family relations combined forces to get a minister of religion from the Netherlands to serve among dissatisfied groups in the Orange Free State, Magaliesburg and Lydenburg. ${ }^{48}$

Vice-president Venter of the Orange Free State, who had had no formal education, was an intelligent, headstrong man - a unique and picturesque character. In 1858 Venter informed the Church Council of the NGK in Bloemfontein where Andrew Murray was the minister, that, much to his regret, his conscientious objections compelled him to resign as a member of the congregation. He referred to the Evangelical Hymns and the doctrines taught in the church, the manner in which public worship (which included methodist-like prayer meetings) and confirmation were conducted. He also voiced dissatisfaction with the way in which the gospel was preached. He took his example from Abraham and Lot and with no ill feelings resigned the Dutch Reformed Congregation of Bloemfontein. ${ }^{49} \mathrm{~A}$ few families joined Venter in his withdrawal from the DRC. ${ }^{50}$ In the mean time, on the 10 th of March 1858, Venter took action after he had obtained limited information from a Dutch immigrant about conservative ministers within the Netherlands. Already in 1856 Venter had extended on behalf of himself and Lydenburg an open invitation by calling on a certain rev Callenbach to come and minister the reformed gospel to Venter and those whom he represented. He asked the same day the Dutch elder Van Andel's support to obtain a minister of strict 
reformed convictions. ${ }^{51}$ The only requirement was that such a person should adhere to the traditional Reformed religion and public worship according to the standards of the Synod of Dordrecht 1618/19.

Venter assured of support from Lydenburg, committed himself financially to the project by pledging all his possessions because of his overwhelming longing to go "in godshuijs met vreugde". ${ }^{22}$ Like all Doppers, Venter had no knowledge of the secession of 1834 in the Netherlands. No denominational or institutional identity whatsoever of Callenbach or Van Andel was implied in his call. He merely endeavoured to obtain a reformed ministry on local congregational level. The founding of a new denomination was not in his mind. He vaguely identified ministers on account of their personal convictions in regard to the reformed faith, and not because of their institutional connections.

Venter's initiative was responded to by the Synod of the Christian Reformed Church of the Netherlands (CGKN) after Van Andel had mediated in 1857. The synod delegated the rev Dirk Postma to offer help in the form of ministers and teachers of this church to the Government of the Republic of Transvaal. At that time there were only one minister and three teachers in the Transvaal. ${ }^{33}$ The Synod obviously had no or very little knowledge of the ecclesiastical tensions in the Transvaal. It is remarkable that a reply to Venter's communications to Van Andel deals with the Government of the Transvaal and not with Venter in the Free State. The connection of Venter with Lydenburg may explain this.

\section{THE STRUGGLE FOR FREEDOM OF CONSCIENCE IN THE} TRANSVAAL 1853 - 1859

Strong pro-British colonial sentiments against the Great Trek prevailed at the Dutch Reformed Synod of 1837 in Cape Town. It enforced an ecclesiastical ban on the Voortrekkers and prohibited any minister to administer sacraments to them. This attitude began to change only in 1847 . When Sir Harry Smith in 1848 proclaimed the Orange Free State as British territory, he described the provision of a minister of religion as one of the advantages of British rule. Some Transvalers, namely the Pretorius-party clashed with Smith in a skirmish at Boomplaas 1848. They were after that the more convinced that the alliance between the Cape Colonial British Government and the Cape Church presented a grave threat to their independence in the Transvaal. They objected strongly against the attempts of the Cape Synod of 1852 to incorporate the Transvaal churches. In the same year Britain suddenly recognised the political independence of Transvaal.

In 1853 candidate-minister Dirk van der Hoff unexpectedly arrived from the Netherlands in the Transvaal. The Volksraad and Government immediately founded the Nederduitsch Hervormde Kerk (NHK) as church of the state, independent from the Cape Synod of the DRC (NGK). It was believed that closer ecclesiastical ties with the state church in the British Colony would jeopardize the newly won political independence. ${ }^{34}$

In the Constitution which was accepted in 1858 , provision was made for an official state church, the independent country's own church. In 1863

68 - In die Skriflig 1989, 23 (4) 
the laws and bylaws of the NGK of the Cape Colony were adopted for the NHK."s

When the Volksraad and the church assembly ordained the rev Van der Hoff as the one and only minister in the church of state at Rustenburg in 1853, the compulsory singing from the Hymnal also came to the fore. ${ }^{\text {s }}$ The opposition ranged from the moderate need for reassurance of some of the few Doppers from Colesberg to the demands of the radical Enslin group. The Doppers wanted to be reassured that they would not be forced to sing hymns or alternatively would be convinced with proof from Scripture that these hymns did not introduce a 'new gospel' into public worship. The radical Enslin group demanded the hymns to be removed from public worship alltogether.

In a pastoral letter, titled Eene Stem uit Mooirivier and circulated during 1855, the rev Van der Hoff stated on behalf of the General Assembly his unwillingness to take up the challenge to proof the hymns from Scripture "want overtuigen kunnen wij die menschen toch niet". ${ }^{77}$ He even disillusioned the head of state by implying that he could not call on the Synod of Dordt of 1618/19 because that would proof him in the wrong.ss One of the Doppers, P. A. Venter, reacted likewise in a printed circular against Eene Stem uit Mooirivier in which he testified to the sole authority of Scripture. He claimed being ministered in such a way by the rev Van der Hoff added insult to injury. ${ }^{99}$ In this important and far-reaching publication Venter drew attention to local worship and the Scriptural basis of authority which Van der Hoff ignored. He called on J. H. Venter, a relation of his in Lydenburg. ${ }^{\circ}$ It seems as if this movement had triggered off the action of $\mathbf{J}$. $J$. Venter in the OFS in connection with Lydenburg to get a reformed minister from the Netherlands. ${ }^{\text {.1 }}$

The matter was further complicated because P. A. Venter and his supporters sided politically with Schoeman opposing M. W. Pretorius. ${ }^{62}$ Towards the end of 1857 schism was in the air in Rustenburg. According to the magistrate Robinson, people resigned because of Van der Hoff's attitude. They wanted to have a church supported by themselves and subjected to Christ alone ${ }^{63}$ They even considered ties with the Cape Synod. They were clearly working on a solution for their problems with the local worship and to achieve a church polity where the authority of Scriptures would be uphold.

To safeguard his position and power in the church and also his salary from the state, Van der Hoff tried to prevent the congregation of Lydenburg to get their own minister. This caused a snowballing conflict with M. W. Pretorius. Shortly after the circular of P. A. Venter in July 1856 Ph. Snyman, an elder of Rustenburg, lodged a complaint with Pretorius that the ecclesiastical affairs of the State Church had not been conducted by Van der Hoff in accordance with the norms laid down by what he called "ons algemeen Sijnoden nationaal gehouden te Dordrecht in het jaar 16 honderd 18 en 19 ." He mentioned that for this reason he would be compelled to join a secession which was already taking place in Rustenburg, most probably related to the positions taken by Lydenburg and $\mathbf{J}$. $\mathbf{J}$. Venter in the OFS. Tension and discord erupted in different but influential parts of the young and still disorderly Republic of Transvaal os

In die Skriflig $1989,23(4)-69$ 
Pretorius tried most strongly to get an antipode against the rev Van der Hoff's ambition to become chief minister. He even negotiated, officially but unsuccessfully to get a minister from the DRC (NGK) in the Cape Colony to serve in a congregation on the basis of "Godswoord en de verordeningen . . . te Dordrecht van 1618 en 1619". ${ }^{.5}$ This was a deliberate effort of the president to consolidate the young Republic by establishing relations with Lydenburg as well as the so-called "Psalmsingers".

With schism in the air the young talented Paul Kruger (1825 - 1904) intervened and came to the rescue. He supported Pretorius's endeavours to unite the striving parties in the young republic on the basis of a constitution. He was already the power behind the constitutional movement which must inter alia prescribe the standards of Dordrecht as basis for ecclesiastical unity. He rejected the plan to secede in order to join the Cape Synod. Kruger might even have been informed about J. J. Venter's initiatives in the OFS and the support he had secured from the Schoeman party as well as from Lydenburg. ${ }^{66}$

Kruger envisaged a way to recognise conscientious differences on local level within the unity of the Transvaal Church. The proposed constitution promised to uphold the standards of the Synod of Dordrecht 1618/19 for the sake of unity of the church even when diversity in local worship should be allowed. ${ }^{67} \mathrm{He}$ also reconciled the striving political parties in 1858 on the basis of a constitution. The idea to join the Cape Synod lost impetus. Kruger believed that on the basis of local diversity and unity in the essentials, consolidation of the church and state was possible.

The Constitution of the Transvaal was unanimously accepted in 1858 . The state would allow only ministers of religion who complied with the requirement about the standards of Dordrecht 1618/19. Kruger therefore suggested that the conscientious objectors accepting the Constitution, were granted the freedom to worship in a separate congregation, in accordance with their convictions.

When the news arrived that the rev D. Postma was on his way to the Government of the Transvaal, the Church Council of Rustenburg gave permission in August 1858 that he may officiate in a congregation according to the wishes of the group who had opposed the rev Van der Hoff. This agreement was forwarded to the Government and endorsed by the Volksraad on 20 September $1858 .^{68}$ There was hope in the air that a breach in church affairs had been avoided.

All the efforts endeavoured to solve the problems in connection with local worship and ministry. The institution of a denomination in opposition to the General Assembly recognised by the Constitution had not been considered or pursued.

\section{THE DIE IS CAST IN TRANSVAAL 1858 - 1859}

According to the agreement at Rustenburg in August 1858 a committee under leadership of the Cmdt Paul Kruger should fetch the rev Dirk Postma from Natal. He was mandated by the CGK to offer help to the young state of Transvaal by providing in the dire need of ministers and teachers. Ironically, the Government had passed the notification of

70 - In die Skriflig 1989, 23 (4) 
Postma's arrival on to the Church Council of Rustenburg who again transferred the obligation to a committee representing those who would be allowed to be administered to in a separate congregation. Although the CGK sent an official delegate to the authorities in the Transvaal he was beforehand officially destinated to serve as minister of a special congregation within the fellowship of the state church. If Postma did not please them, they were responsible for his return to Natal. If he complied with the requirements of the Constitution they could have him. ${ }^{69}$

Postma arrived in Transvaal in November 1858. In his diary he recorded his shock at realizing that the Transvaal church was on the brink of a secession. He may have sensed that his mission to Transvaal was already jeopardized in the way his reception was handled. He discussed the matter with Van der Hoff in a brotherly fashion and they agreed to settle the problems by means of indulgence. ${ }^{70}$

The General Assembly of the Transvaal Church gathered on the 11th of January 1859 in Pretoria in order to establish whether Postma would comply with the standards of the Synod of Dordrecht 1618/19. The chairman and only other minister present was Van der Hoff. He came from the NHK (state church) in the Netherlands who looked down with contempt on the CGK where the rev Postma came from. In the two Dutch ministers a clash between denominations was signalled. Van der Hoff must have loathed the idea of having a minister from the seceded CGK as his only colleague among a conservative Transvaal population, the more so because prospects were that more ministers from that side might arrive. For the first time, although initially unobserved, a denominational factor of which Van der Hoff was very conscious as he had admitted in April 1858, began to play a part."1

He had just settled a serious conflict with Lydenburg and president Pretorius on the issue of more than one minister in the church of state. ${ }^{12}$ He would not like to give up his position to ministers of the CGK of the Netherlands. He therefore had to play his hand cautiously.

It was a formality to establish that Postma adhered to the standards of Dordt 1618/19. Nobody commented on the breach of agenda when the chairman, in spite of the official agreement on this matter in September 1858, asked for Postma's view on the matter of singing Evangelical Hymns in public worship.

Postma replied in writing: ${ }^{73}$

(1) When a church is at peace with singing hymns, he would not pass judgement against such a church.

(2) To abide by the rule of the Church Order of Dordt (Art 69) would be the safest way.

(3) If some people have conscientious objections against hymns which are not based on Scripture, unity and love ought to impel others to cease singing such hymns.

(4) If that is impossible to achieve, the matter should be left to the conscience of every minister to conduct services according to the situat- 
ion in every congregation so as to prevent by all means secession for such a reason.

The Assembly then stated that the NHK would maintain its Evangelical Hymns because it was not a secessionist Christian Reformed Church. Thus the agreement of September 1858 was jeopardized, the singing of Hymns officially prescribed and compelled and the attempts of President Pretorius and Pau! Kruger to achieve a modus vivendi by means of conscientious freedom within the unity of the state church were made undone. The assembly had cast the die.

The 1 llowing day fifteen prominent leaders including Commandant Paul Kruger, informed the General Assembly that they would depart from the "community of your church and desire to live as a Free Reformed Church (Vrye Gereformeerde Kerk) in accordance with the teachings, discipline and devotion of the fathers as revealed in the Synod of Dordt in 1618 and 1619". They declared their heartfelt sorrow at the step taken but said that they believed and prayed that the existing mutual brotherly love between the two (take note) 'congregations' would not weaken and that with regard to the existing differences they would bear with one another in affection. They even prayed that God might again re-unite them in worship as well as in doctrine. They mentioned that the Commission which had been appointed during August 1858 by the Hervormde Church Council of Rustenburg in connection with the rev Postma would henceforth act independently. ${ }^{74}$

\section{SECESSION MATERIALISES IN 1859 IN THE TRANSVAAI.}

On the 10th of February 1859 three hundred and ten people enrolled in Rustenburg to be the Reformed congregation or church of the Zuid-Afrikaansche Republiek. They elected elders and deacons and called upon the rev Dirk Postma of the CGK of the Netherlands to become their pastor. ${ }^{75}$ They notified the Government that this new congregation fully corresponded in doctrine, service and discipline with the Reformed Church as determined by the Synod of Dordrecht 1618 and 1619 .

It is remarkable that although the rev Postma belonged to the CGK they never envisaged or contemplated joining the CGK or founding such a denomination in South Africa. They did not look upon the church as a denomination or legal persona. No constitution was drafted or accepted on the 10th of February. They simply enrolled in order to receive the services of the rev Postma. They only had the passion to worship God according to their conscience. Their priority was the ministry of the congregation, according to the standards of the Synod of Dordrecht. ${ }^{76}$

As far as the rev Postma was concerned, however, he was acquainted with the idea of a denomination. He therefore tried to draft a constitution and turned the Church Council on this purpose over to a General Assembly on the 12th of February 1859."

\section{SECESSION FROM THE DUTCH REFORMED CHURCH IN THE OFS IN 1859}

During May $1859 \mathrm{~J}$. J. Venter and supporters of the same faith gathered

72 - In die Skriflig 1989, 23 (4) 
at Torbrek near Bloemfontein, the farm of J. P. van der Walt, the exopponent of the rev Reid in Colesberg. There was again no talk of joining the established CGK of the Netherlands nor even of joining the Reformed Church of Transvaal. They also simply assembled and ordained elders and deacons because they wanted to be recognised as another Free Reformed Church where the reformed religion is administered. ${ }^{78}$ The Government had to be notified of this event on special reguest by the members. They wanted to be an independent "Gereformeerde Gemeente die in Leer, Dienst en Tucht overeenkomt met de Gereformeerde Kerk van Nederland, zooals die zich heeft geopenbaard te Dordrecht in de jaren 1618 en 1619 . . . De Kerkeraad van opgemelde gemeente beveelt zich met dezelve . . . aan de geeerbiedigde Overheid . . "

Although Postma may have cherished the idea of denominational unity with Rustenburg, ${ }^{80}$ the ordinary people were motivated on congregational level to receive the ministry of Postma rather than to join a particular denomination. ${ }^{81}$ Denominational identity did not motivate the rank and file among the Doppers at this stage.

\section{SECESSION FROM THE DUTCH REFORMED CHURCH \\ IN THE CAPE COLONY 1860}

Independent and autonomous congregations organised themselves likewise in the Cape Colony at Burgersdorp (January 1860), Middelburg and Colesberg (December 1860). Everyone of these local churches notified the Governor of the Cape Colony independently of existence without mentioning denominational unity among them. ${ }^{82}$ It is ironical that Colesberg, where the struggle had started, should be the last in the row of five autonomous, independent and free Reformed congregations or churches.

\section{COOPERATION AMONG THE FIVE CORRESPONDING CHURCHES}

Ecclesiastical fellowship was established in 1862 between these five autonomous churches when they adopted the Church Code (Kerkorde) of the Synod of Dordrecht 1619 as the common basis for a federal synodical fellowship, cooperation and mutual assistance in ecclesiological matters. ${ }^{83}$ This Church Code can in no ways be judged a constitution to establish a denomination. It is rather an agreement to ensure cooperation between local churches in certain ecclesiastical matters."

This unity in inner conviction and outward cooperation across the existing colonial and political borders to which the other Afrikaans speaking Churches were confined, was of immense importance for future ecclesiastical and cultural development in South Africa.

\section{IMMEDIATE EFFORTS TO RESTORE UNITY}

President M. W. Pretorius and his Government in the Transvaal immediately called for another meeting of the General Church Assembly in order to revise its decision of the 11th January 1859. The outcome of this decision violated on the one hand the official understanding of September 1858 and on the other jeopardized political unity which Pretorius hoped to achieve, even with the OFS. The Government instructed the General 
Assembly to restore unity by practising love and recognising the principle of local freedom within the broader unity of the state church. The Government even invited ministers of the DRC from the Orange Free State as well as one from the Cape Colony, apparently to neutralise Van der Hoff's dominance.

This move proved to be a fatal one. Van der Hoff and the DRC ministers (one of which was the dominating and aggressive Hofmeyer of Colesberg) were allies in the campaign to isolate the "Doppers" and to dismiss influence from the CGK because they were traditionally linked to the Hervormde Church of the Netherlands.

Postma and Paul Kruger were summoned as witnesses to the meeting but treated as accused. They tried in vain to point out that they had seceded because of the "hierarchie of kerkheerschappy," the "overheersching en onregt" and the "onderdrukking der minderheid." They were not even listened to. The NHK and NGK ministers could not see past the question of the Hymnal which Postma and Kruger plainly did not regard the crucial issue. ${ }^{85}$ It is clear that Postma and Kruger approached the issue from the quality of ministries and church polity exercised while the Church Assembly dealt with denominational uniformity.

The Church Assembly resolved naively that the rev Postma could serve under the supervision of the rev Van der Hoff in a congregation within the structure of the NHK without using Evangelical Hymns. The Assembly then notified the Government that the Reformed Church had thereby ceased to exist in Transvaal. "Dit besluit worde genomen met het doel om de Nederlandsche Gereformeerde Kerk alhier met hare instellingen te handhaven aangezien de kerk niet is eene afgescheidene kerk."

The Reformed People in the ZAR (GK) did not take this high-handed and offending resolution seriously. They simply pointed out that after secession had been forced on them they were not merely a NHK or NGK congregation without hymns. Unity could only be restored on the foundation of the doctrine, service and discipline as established by the Synod of Dordt 1618 and 1619. They said that they had done everything to prevent a religious split. They had gone this far and were not prepared to abandon now anymore the Reformed freedom and institution they had founded. Considering the undeniable absence of unity in spirit and faith, an organisational unity could no longer be considered by them. ${ }^{87}$ Spiritual unity was the absolute condition for ecclesiastical unity which they longed to achieve. ${ }^{88}$

\section{IN CONCLUSION}

The Doppers struggled as simple people during the 19th century against the sophisticated onslaught of liberalism and modernism. ${ }^{\text {.9 }}$ The NGK and NHK conceded nearly a century later officially that the Hymnal had to be revised on doctrinal grounds. ${ }^{90}$ The merits of the struggle and character of the uneducated objectors without theological guidance changed the nickname 'Doppers' in the course of time to a name of honour.

The recurring refrain in their conscientious struggle was: are the changes ('nuwighede') which are forced upon us in accordance with the teach-

74 - In die Skriflig 1989, 23 (4) 
ings of the Holy Scripture? This repeated appeal was set aside over many years by various ecclesiastical bodies. They never gave the objectionists a fair trial nor did they try to understand, tolerate or appreciate their sincere beliefs. Until today the differences are reduced from the side of NGK and NHK to the question of the hymns (e.g. Van der Watt 1987). This perception may originate from the official endeavour to force the hymns by any means of the objectors. When the effort failed the objectors had to take the blame for the secession on account of the hymns.

This is a misrepresentation. The truth is that ministers and ecclesiastical bodies forced secession on sincere believers by means of ecclesiastical pressure and procedures meant to enforce the hymns. The objectionists held on firmly to the basic principle of the Reformation, (i.e. article 7 of the Belgic Confession.9 ${ }^{9}$ )

The Enlightment of the 18th Century changed the content of religion, the concept of authority and the perception of the church. The majority vote in the Presbytery and Synod replaced the sola scriptura principle as supreme authority in centralised church assemblies. A clash with the secluded Doppers who traditionally enjoyed individual freedom and local responsibility in sole obedience to the Word of God, was inevitable. Perhaps the most remarkable difference between these simple people and their sophisticated adversaries was their concern and care for the local ministry and worship. Their conduct was determined by the question: "Is het naar Gods woord?"

In contrast to this on strength of the General Assembly of the NHK in April 1859, it can be asserted that the ministers of religion tried to safeguard denominational structures according to the new denominational nature of the church introduced by De Mist in 1804 and the DRC Synod in 1824. One may make bold to state that this formal organisational and institutional concept of the church as an uniform body caused many secessions and schisms in churches of reformed tradition during the 19th century, all over the Western world. Van der Watt ${ }^{92}$ described a wide range of different secessions in the DRC. In almost every case the dominating cause for secession can be traced down to local resistance against dominance of centralised ecclesiastical bodies in a time when a strong sense of individual freedom and local responsibility still prevailed in rural and patriarchal communities.

The ecclesiastical bodies failed from 1841 to 1859 because the issues were not determined by the question whether the objectors were true believers and entitled on a ministry as ordained by Jesus Christ even when prohibitions should be observed. Instead, acceptance of the Hymnal was made an absolute prerequisite to formal denominational unity. Uniformity in views upon a Hymnal was of greater importance than the unity of faith within the body of Christ.

The objectionists were immensely sensitive to horisontal or human authority which tried to pressurise them into a compulsory religion.93 Perhaps because theological leadership was wanting among the Doppers, they did not apply the marks of the true church as was done in the Netherlands in $1834^{94}$ to a denominational church or a centralised

In die Skriflig 1989, 23 (4) - 75 
synodical institution. They were concerned with local ministry, unity in faith, worship and discipline according to the norms of the Synod of Dordt 1618/19.

They could rejoice after a sermon of Postma: "Vandag hebben wij weder Smijtegeld gehoord." They believed that by upholding consentious responsibility they once again could worship the Lord according to their understanding of his Word. ${ }^{95}$

The Church Council in the Free State (where Vice-president Koos Venter was an elder) explained the reason for secession to prof. Helenius de Cock in the Netherlands on the 14th January 1860, inter alia like this: "In connection with the discipline in the church our lack of knowledge hampered us to detect exactly what was wrong in the numerous regulations. Nevertheless, we were able to see and experience this ecclesiastical discipline to be of a worldly nature. We were forced simply because Synod had decided - if only it had been a regulation. It was too infrequently or never at all asked whether or not the decision was according to God's Word ... If Synod or Presbytery had passed judgement we were compelled to obey ..."

The result to this experience is today known as the Reformed Churches in South Africa (GKSA). The real issue from 1834 to 1860 was to a great extent the clash between simple, Godfearing people with fixed ideas and expectations in connection with ministry and worship in the local church as a body of Christ with sophisticated leaders who cherished the idea of uniformity in the church as an organisation under their leadership.

\section{NOTES}

1 General: For the sake of readability extensive historical documentary references compelled notes below the text and are not given according to the Harvard-method.

2 Calvin. 1931: IV.1.(10)-(12), (22).

3 The spirit and conviction of article 7. Belgic Confession revealed itself in numerous documents, the frequent occuring question whether something is "naar Gods Woord". The important Pastoral Circular of the Presbytery Graaff Reinet (R 3/3. Appendix N, 20.11.41) tried therefore to refute this fundamental argument. Secessionists founded their convictions on this principle. viz eg G.K. Reddersburg to De Cock 14.1.60 in Van der Vyver, 1958:489. Appendix 4; Beyer, $1866(1863): 241-243$, 248: Viz Huet, 1872:3 and Spoelstra, 1963:183 note 116 etc. This point of departure already excluded a denominational approach to the problems in the mid 19th century.

4 Loots 1962:60 etc; Murray, 1976:8f; Spoelstra, 1980:3f.

5 Viz Spoelstra. 1963:12-32 re Doppers.

6 Murray, 1954:49f; Spoelstra, 1963:17f.

7 Murray, 1877:379.

8 Zwerfgraag. 1857

9 Van der Merwe, 1937:156. GK 288, 28.8.18 Mossop, 1947:249; Spoelstra, 1963:30f.

10 Spoelstra, 1963:16-32.

11 Viz Spoelstra, 1963:63f, Van der Vyver, 1958:193f, Kruger, 1957:82-105.

12 Spoelstra, 1963:16f, 117, 175, 182, $219 f$

13 Jooste, 1946:80f; Dreyer, 1936:8f

14 Dreyer, 1936:368f ; Van der Walt, 1980:3f; Spoelstra, 1963:35f.

15 Spoelstra, 1963: 36.

16 Van der Watt, 1980:38f.

17 Spoelstra, 1989.

18 Hanekom. 1951:156-250, 439.

76 - In die Skriflig 1989, 23 (4) 
19 Hanekom, 1951:59, 179: Zwerfgraag, 1857.

20 Spoelstra, 1963:189f. viz Geref. Kerk Middelburg. 1911:19, 13, Cachet 1909:51, 55, $59,63,65,71$; GKSA, 1910:28

21 Geref. Kerk Middelburg, 1910:25f; KKA, Cradock 9.11.33; R 3/1:62, 21.11.33.

22 Viz, Spoelstra, 1963:115f, Jerusalemgangers.

23 Kruger, 1957:82f, viz documents; Spoelstra, 1963:66f ref KKA, Colesberg, 3.2 40, 3.4.40, 4.5.40

24 KKA, Colesberg 2.8.41, 1.11.41 viz 30.9.41. The rev T. Reid may have been the driving force behind it, viz. Supreme Court, Civil Cases 1856, Vol 3 no 37, Spoelstra, 1963:64f.

25 KKA R 3/3 appendix N 20.11.41, also GKSA, Acts 1969:41f, Herderlijke Brief van den Graaff-Reinetsche Ring aan de Gemeentes van Colesberg en Cradock. Grahamstad, 1842.

26 Van der Vyver, 1958:277.

27 Viz Du Plooy, 1989.

28 Spoelstra, 1989.

29 KKA S 1/8, p 605 Appendix 69, J. H. Venter viz R 3/4, p 7, 77; 1843; Ibid. P. 330, 15.10.46; Viz KKA, Colesberg 7.11.43, 5.5.45, 2.6.45, 2.8.47. Viz Spoelstra, 1963:69f, Kruger, 1957:95-103.

30 KKA. R 3/5:150-152, J. H. Venter 18.10.49.

31 Supreme Court, Civil Cases 1856, Vol 3, No 37, J. P. vd Walt; KKA R 3/5:258f, 285-291.

32 KKA, R 3/5:270f, viz 258f, 285-291 petitions 1849.

33 Supreme Court. Civil Cases 1856: Vol 3, No's 37, 38, 41, 42 etc. Viz Spoelstra 1963:81, Note 138.

34 KKA R 3/5:446-448; S 3, 1/4:310, 323, 345-366, Knobel Celliers to Aktuaris 20.7.52, 18.8.52, Colesberg to Actuary 1.7.52; Ibid 1/9:339f, App. 1, 2, J. P. vd Walt, 17.9.52 Viz 15f. A. Murray (13.10.52), 89, 97-102, 110f, 128-135, 955f Appendix W, Advisary Committee.

35 Spoelstra, 1963:77f.

36 KKA S 1/9, 110f, 133-137, 955f.

37 Supreme Court, Civil Cases, 1856: Vol 3:96f. 106 No's 37, 38; Ibid 96f Nr 37, Appendix, agreement 14.10 .63 by notary public. Ziervogel; KKA R 3/6:7, 14.10.53, viz Ibid:1, 13.10 .53 .

38 Supreme Court, Civil Cases, 1856 Vol 3 and 4 : No's 37, 38, 41, 41.

39 Viz Spoelstra 1963:84.

40 KKA R 315, 10, 11, 11.10.1848. Viz Spoelstra, 1963:161.

41 Zwerfgraag 1957.

42 Huet, $1860: 328 f$.

43 Kruger, 1957: 118 note 55, Presbytery 31.10.53 art 12; Muller, 1907:41; Van Schoor, 1950:167; Spoelstra, 1963:149f. 155f.

44 Jooste, 1958:22.

45 Coetzee, $1986: 31 \mathrm{f}, 163-175,204,226 f$.

46 KKA R 3/5 (1848) : 50, 71, 211 (1849) Taylor: 351 (1850) and 491f (1851): J Murray; Du Plessis, $1920: 189 f$, Andrew to John Murray 1.5.1859; Postma, 1905:234, J. A. Kruger: Spoelstra, 1963:165 note 191; Van der Vyver, 1958:489.

47 Huet, 1860:328f; 1872:20f, 46: Kruger, 1957:126; Spoelstra, 1963:50.

48 Viz Spoelstra, 1963:157f.

49 GKSA PV 25: Venter to DRC Bloemfontein, 21.1.58 and Venter Acquisitions: Venter to DRC Bloemfontein 8.2.58. Viz Kruger, 1957: 120f; Van der Vyver, 1958:268f; Spoelstra, $1963: 158 f$.

50) Viz Kruger, 1957:121, Venter et al to the Congregation, Bloemfontein 30.3.58.

51 OFS, Supreme Court 907, Appendix 13, Callenbach to Lydenburg, viz Van der Vyver. 1958:154 and 15. Venter to Van Andel, 10.3.58. Viz Kruger, 1957:123

52 Ibid., Venter to Van Andel 10.3.58.

53 Van der Vyver, 1958:153-172.

54 Viz Engelbrecht, 1953:84-99.

55 Engelbrecht, 1953:132-138; Spoelstra, 1963:110.

56 TKA. NHK I: 21, 26.12.55; Ibid:6a, 6. Paul Kruger et al, 9.8.53; Gerdener, $1930: 577$, Zuid Oost Afrikaan 18.11.53; EVR 3, 9.8.53 artt 20,21 re Hans and Jacob Erasmus; Viz Spoelstra, 1963:118f; Spoelstra, 1982: 152f, 157f; Claassen, 1981 
57 Van der Hoff, et al 1858:54.

58 SS II. R $969 / 56$, Pretorius to Van der Hoff 18.1 .56

59 Venter, sa viz Spoelstra, 1963:123; Spoelstra. 1982:158f.

60 GKSA Archives, Acquisitions 184. Viz OFS, Supreme Court 1979:907, Appendix XIV, Van Andel to S. J. Kruger, P. S. Snyman, P. Venter (a brother of J. J. Venter of the OFS), and P. A. Venter, 28.8.57. It could not be established whether this J. H. Venter was previously from Colesberg.

61 Viz Spoelstra, 1963:124, 158f. Research may reveal interesting inter-family communications.

62 R 1871/58, minutes 23.1.58 viz Spoelstra, 1963:132.

63 SS 17, R 1795/57, 23.11.57, 23.11.57; R 1789/57 viz Spoelstra 1982: 164. J. J. Venter's withdrawal from the DRC. Bloemfontein and call on any reformed Dutch Minister 10.3.58 indicates communications between discontented groups in the Transvaal, OFS and North Eastern Cape Colony.

64 R 1132/62, Snyman to Pretorius 6.7.1856. Viz Spoelstra, 1963:118-126.

65 SS 22, R 2523/58: No 10: Pretorius to Neethling 11.1.58. Viz Spoelstra, 1963:126, 131.

$66 \mathrm{Viz}$ Spoelstra, 1982:161f.

67 Ibid: 165 .

68 Gerdener, 1930:231, Session Rustenburg 30.8.58 SS 21, R 229/58. P. and S. J. Kruger to Government 14.9.58. EVR 20.9.58, art. 20 approved by the Volksraad.

69 T.K.A. NHK I:62f, 26.4.59; Gerdener, $1930: 231$, Rustenburg 30.8.59. The official handling of the Postma delegation stands in contrast with the offer to Berrange 11.1 .58 in $\mathrm{R} \mathrm{2523/58, \textrm {nr } 8 .}$

70 GKSA, PV 445 I. Postma Journaal, 15th Nov ff ; Postma, 1905 : 108, Postma to CGK 3.12.58; Gerdener, 1930:642f: Spoelstra, 1982:164-166

71 TKA, NHK I:94, 28.4.59. Viz Spoelstra, 1963:197.

72 Spoelstra, 182:155; Engelbrecht, 1953:105-132.

73 Viz Postma, 1905:119-120.

74 Viz Ibid: 124.

75 Viz Ibid: 134-142; GKSA-A, PV 445, I, sub 10.2.59.

76 Staats Courant ZAR 18.2.59: Openlijke Verklaring 12.2.59. SS 52:120f, Geref Kerk of ZAR to Government 12.2.59.

77 Viz Spoelstra 1963:172.

78 GKSA PV 445, I sub 11th May f; Postma, 1905: 166.

79 Postma, 1905:170. Viz PV 445 op cit sub 6 th June 1859

80 Viz Postma neglected notification of the OFS Government on the 12th May and had been called upon to do so on the 6th of June 1859, PV 445 op cit sub 6th June 1859.

$81 \mathrm{Eg}$ members from Colesberg motivated their action to be "onder de vanen van den Eerw Postma", viz De Vriend 19.8.59 and KKA, Colesberg 6.2.60, re J. A. Venter.

$82 \mathrm{CO} 760$, Church Council to Governor 28.2.60, Church Council (Middelburg) to Governor 3.12.60 and Colesberg, viz Spoelstra, 1963:180 note 95

83 Handelingen van de eerste algemeene sijnodale Vergadering der Gereformeerde Kerk, van de ZAR, OVS en de Kaap-kolonie in Zuid-Afrika, 20-24 Maart 1862 te Reddersburg (Saul Solomon, Kaapstad), artt 12, 14, 19. The Synod was viewed as an ad hoc gathering of churches (ibid art 20), not a permanent institutional structure.

84 Spoelstra, 1989(b):4f, $19 f$.

85 TKA, NHK I: 64-76, 80f, 91f; PV 445, I: sub 26.4.59; Postma, 1905:159f, 165.

86 TKA, NHK I:94. Viz Spoelstra, 1963:197.

87 SS 26, R 2810/59: Alg Verg GK aan UR, 1.8.59; Het Volksblad 29.9.59 re idem; GKSA, PV 445, I: sub 1.8.59.

88 Handelingen van de eerste algemene sijnodale Vergadering . . Maart 1862: art 12, Openlyke Verklaring.

89 Hanekom, 1951:59, 179.

90 Preface. "Psalms en Gesange" in Afrikaans 1941; Van der Walt, 1962:9, W. E. G. Louw; Van der Vyver, 1958:202-212

91 Viz Huet, 1860:324 and note 3 above.

92 Viz Van der Watt 1977 , where the dominating cause for secession may time and

78 - In die Skriflig 1989, 23 (4) 
again be traced to local congregational resistance against centralised ecclesiastical bodies.

93 Viz Spoelstra, 1963:72, 119, 129, 141, 160, 197, etc.

94 Viz Rullmann, 1916:146, Acte van Afscheiding of Wederkeering, Ulrum: 13.10.1834 in which the denomination as a whole and not local congregations where the marks were applicable, was stamped a false church.

95 HKA, SPE XI/9:11, G. S. van Biljon, 24.9.01; Viz Spoelstra, 1963:24, 67f, 114, 123 , $160 f, 183 f, 188$.

96 Viz, Appendix 4, Van der Vyver, 1958:489

\section{BIBLIOGRAPHY}

Beyer, T. 1863. Openlijke Verklaring of Redenen waarom velen zich hebben afgescheiden van de Ned. Ger. Kerk en de Gronden der Gereformeerde Kerk in Zuid-Afrika Cape Town: Solomon \& Beijer.

Cachet, JL. 1909. Gedenkboek van het 50-jarig bestaan der Gereformeerde Kerk van Zuid-Afrika. AD 1859 - 1909. Potchefstroom: Koomans.

Calvyn, J. 1931. Institutie; of onderwijzing in den Christelijke Godsdienst. Uit Latyn vert, deur A. Sizoo. Delft: Meinema.

Claasen, JP. 1981. Die Jerusalemgangers. Pietersburg: s.n.

Coetzee, CFC. 1986. Die werk van die Heilige Gees in die teologiese denke van Andrew Murray. Potchefstroom: PU vir CHO.

Dreyer, A. 1936. Boustowwe vir die geskiedenis van die Ned. Geref. Kerke in SuidAfrika. Deel III. 1804 - 1836. Kaapstad: HAUM.

Du Plooy, A le R. 1989. Kollegialisme. Kerkhistoriese Werkgemeenskap van SuidAfrika. Referaat Jan. 1989. Potchefstroom.

Du Plessis, J. 1920. Het leven van Andrew Murray. Kaapstad: Zuid Afrikaansche Bijbelvereniging.

Engelbrecht, SP. 1953. Geskiedenis van de Nederduitsch Hervormde Kerk van Afrika Kaapstad - Pretoria: HAUM.

Gerdener, GBA. 1930. Boustowwe vir die Geskiedenis van die Nederduits Gereformeerde Kerk in die Transgariep. Kaapstad: Nasionale Pers.

Geref. Kerk Middelburg CP. 1911. De Vijftigjarige Feestviering te Middelburg KP Burgersdorp: De Stem.

Geref. Kerk in Suid-Afrika. 1910. De Almanak

Hanekom, TN. 1951. Die Liberale Rigting in Suid-Afrika, 'n Kerkhistoriese studie. Stellenbosch: CSV.

Huet, P. 1860. Ds Postma over de gezangen en over de gezangen en afscheiding. ELPIS Algemeen Tijdschrift van Suid Afrika. Part IV :324-333. Cape Town: Van de Sandt de Villiers \& Co.

Huet, P. 1872. Over den Gezangenstrijd in de Hervormde Kerk. Den Helder: sn.

Jooste, JP. 1946. Die verhouding tussen Kerk en Staat aan die Kaap tot die helfte van die $19 \mathrm{e}$ eeu. Bloemfontein: SACUM.

1958. Die Geskiedenis van die Gereformeerde Kerk in Suid-Afrika. Potchefstroom KJBF

Kruger, BR. 1957. Die ontstaan van die Gereformeerde Kerk in Suid-Afrika. Pretoria: $V$ en R Drukkery

Loots, PJ. 1962. Pluralisme in Staat en Kerk. Ongepubliseerde DPhil-proefskrif. Universiteit Kaapstad.

Mossop, EE. 1947. Lives of the Earlier Krugers told in a revised genealogical table. Argiefjaarboek vir SA Geskiedenis

Muller, HPN. 1907. Oude Tyden in den Oranje Vrystaat. Naar Mr H.A.L. Hamelberg's nagelaten papieren beschreven. Leiden: Brill.

Murray. AH. 1976. Die post St Bartholomeusnagliteratuur en die plurale tradisie in Suid-Afrikaanse staatsinstellings en protestantse kerke In die Skriflig, 10(39) :816. September

Murray, J. 1877. Some Characteristics of our Fellow Colonists. The Cape Monthly Magazine: $379 \mathrm{ev}$, December. Cape Town.

Murray, Joyce. 1954. Young Mrs Murray goes to Bloemfontein. Letters 1856 - 60. Cape Town 
Postma, D. 1860. Een woord van ds Postma over de Evangelische Gezangen. ELPIS Algemeen Tijdschrift voor Zuid-Afrika. Deel IV pp 320-323. Kaapstad: Van de Sandt de Villiers en Kie.

__ 1905. De Geschiedenis van de Stichting en ontwikkeling der Gereformeerde Kerk in Zuid Afrika. Paarl: sn

Rullmann, JC. 1916. De Afscheiding in de Nederlandsche Hervormde Kerk der negentiende eeuw. Amsterdam: Kirchner.

Spoelstra. B. 1963. Die "Doppers" in Suid-Afrika 1760 - 1899. Cape Town: Nasionale Pers. 1980. Die beginsel in art $30 \mathrm{KO}$. In die Skriflig, 14(55):3-12, September. 1982. Paul Kruger as lid van die Nederduitsch Hervormde Kerk. (In J. P. Oberholster, red Die kerk in die wêreld. 'n Bundel opstelle. p 150-170. Pretoria: HAUM.) 1989. Presbiterianisme. Kerkhistoriese Werkgemeenskap van Suid-Afrika. Referaat Jan. 1989. Potchefstroom. 1989b. Gereformeerde Kerkreg en Kerkregering. Handboek by die Kerkorde. Hammanskraal.

Supreme Court Cape Colony. Civil Cases 1859, Vol 3 Nr 37 Reid vs H.J. vd Walt; nr 38 Reid vs J.H. Venter; Vol $4 \mathrm{Nr} 41$, Reid vs J.P. vd Walt, Nr 42 Reid vs A. Ortlepp.

Van der Hoff, D et al. 1858. Eene Stem uit Mooi-rivier. Aan de leden der NederduitschGereformeerde Kerk in de Hollandsch-Afrikaansche Republiek 27 Des 1855. ELPIS Algemeen Tijdschrift voor Zuid-Afrika. Deel II pp 47-56. Kaapstad: Van de Sandt de Villiers en Kie.

Van der Merwe, PJ. 1937. Die Noordwaartse Beweging van die Boere voor die Groot Trek (1770 - 1842). Den Haag: Van Stockum \& Zoon.

Van der Vyver, GCP. 1959. Professor Dirk Postma 1818 - 1890. Potchefstroom: Pro Rege.

Van der Walt, JJA. 1962. Die Afrikaanse Psalmmelodiee. Potchefstroom: Pro Rege.

Van der Watt, PB. 1977. Gemeentes - en nogmaals gemeentes. Pretoria: NGKB. 1980. Die Nederduitse Gereformeerde Kerk 1824 - 1905. Pretoria: NGKB. 1987. Kerkskeuring die Afrikaner se kos. INSIG, 1:14, Augustus.

Van Schoor, MCE. 1950. Politieke Groeperinge in die Transgariep. Argiefjaarboek vir SA Geskiedenis II.

Venter, PA sa. Eenig Antwoord op zeker schryven getiteld "De Stem van Mooirivier," waarskynlik 1856 (NHK-argief, SPE IV/2 Nr 10)

Zwerfgraag. 1857. De Doppers. Het Volksblad 10.9.1857 